\title{
Providing low carbon cooling through pile foundations; the effect of thermal cycling on clay strength
}

Miss. Nicola Lazenby

\author{
Dr. Paul Shepley
}

\author{
Dr. Colin Smith
}

\begin{abstract}
Pile foundations provide a low-intrusive mechanism for installing heat exchangers into the ground, especially if the piles are being installed to support the building. The ground temperature is relatively constant at depths $>10 \mathrm{~m}$, providing consistent performance of the heat exchanger to the operator. However, as these piles are also being used to support the building above, a greater understanding of clay's response to temperature must be further identified to allow confidence in their installation. A review of case studies, field tests and laboratory tests illustrates the need for further work in ths area. This paper reports initial results from a series of specialized tests on two types of clay subjected to five thermal cycles, representing the long-term operation of pile foundation heat exchangers, and shows that distinct shrink/swell cycles occur leading to $\sim 5 \%$ reduction in volume over the five cycles for a kaolin clay and $0.5 \%$ for a glacial till..
\end{abstract}

\section{INTRODUCTION}

Pile foundation heat exchangers (PFHX) are a fast growing technology across the world, providing low carbon heating and cooling across the non-domestic sector. As non-domestic building emissions targets are tightened PFHX can help to significantly reduce the carbon emissions associated with air-conditioning in large commercial and public buildings. At present, only 1\% of the current UK heating demand is met by renewable sources. The UK Government predicts that the decarbonisation of the heating sector will be required in order to meet their 2020 and 2050 greenhouse gas targets. By 2020 it is expected that around 40\% of UK commercial floor spaces will be airconditioned, and for the UK climate this is predicted to be a 60/40 cooling split over a year causing seasonal temperature variation in the ground surrounding a pile foundation heat exchanger (PFHX) (Evidence Directorate, 2009). Present levels of uptake are hindered by the uncertainty surrounding their effect on ground strength and pile performance.

PFHX impose a cyclic hot and cold temperature profile onto the ground surrounding the pile in order to meet the heating and cooling demands of a building, as illustrated by Figure 1. PFHX utilise the ground surrounding the pile to source heat during the winter months and sink heat to during the summer months. Busby et al. (2009) found that the variation in the near surface ground temperature throughout the year at a depth exceeding $10 \mathrm{~m}$ showed less than a $5^{\circ} \mathrm{C}$ variation in ground temperature. This makes pile foundations ideal to use as heat exchangers due to the more predictable temperature profile at greater depths compared to ground heat exchangers installed closer to the ground. The effect may also allow the ground to be used to store heat between seasons in regions of low groundwater flow.

Nicola Lazenby (nicola.lazenby@sheffield.ac.uk) is a PhD Researcher, Dr. Paul Shepley is a Lecturer and Dr. Colin Smith is a Senior Lecturer, in Geotechnical Engineering at the Department of Civil and Structural Engineering at the University of Sheffield. 


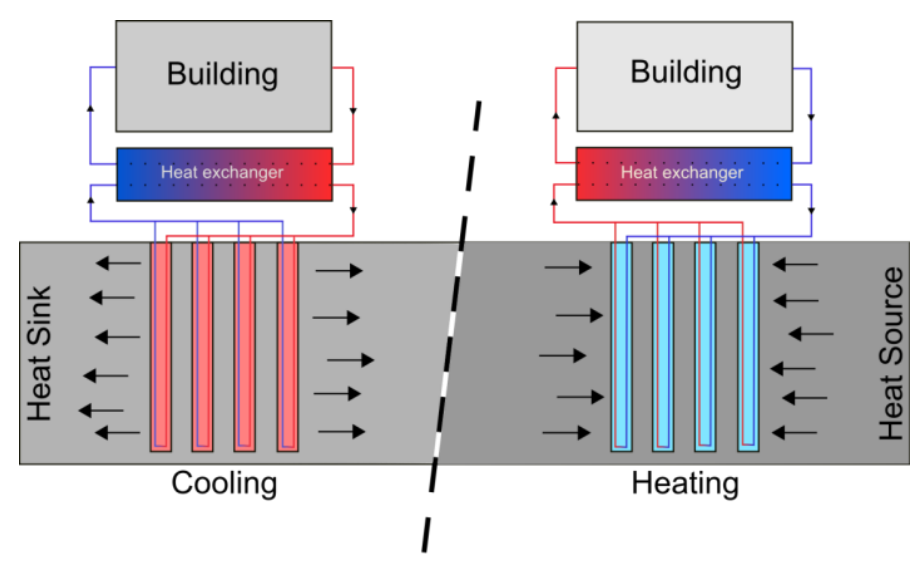

Figure 1 Configuration of a ground source heating and cooling system with pile foundation heat exchangers

\section{CURRENT LITERATURE}

Current literature presents very little information on the influence of cyclic temperature variation in PFHX with respect to the structural performance of the insitu clay in which the piles are installed. Literature is split between case studies of insitu PFHX and laboratory testing on discrete clay samples.

\section{Case studies}

In the current literature there has been a distinct focus on the performance factors of ground source heating and cooling through energy piles and the structural performance of the concrete piles during the heating. Studies tend to focus on a specific clay type, or a specific set of conditions. This study aims to understand the performance of the clay in which PFHX are installed, therefore those case studies that provide potential evidence of the clay's response to thermal cycles are reviewed here.

Bourne-Webb et al. (2011) discussed the hypothesis that a thermal load on an in-situ pile foundation creates expansion and contraction within the pile itself causing axial forces to develop. During a field test on a PFHX, an increase in shaft resistance was observed, which increased by 25 to $75 \mathrm{kPa}$ along the length of the pile during the heating phase, representing as increase in shaft resistance of three times that without heating. This caused a general reduction in axial load along the pile, and the axial load was also observed to become tensile in the low third of the pile. This theory and framework was applied to the authors' case studies at Lambeth College and that of Laloui et al. (2006) at École Polytechnique Fédérale de Lausanne (EPFL). It was found that the hypothesis proposed by BourneWebb et al. (2011) supported the field results from the Lambeth College and EPFL case studies, giving evidence that cyclic temperature variation does impact on the skin friction of a pile foundation. However this study was primarily focused on the effects arising due to thermal expansion of the pile itself.

There is conflicting evidence from different case studies about the mobilisation of skin friction due to thermal cycles. Another case study by Brandl (2006) found during efficient PFHX operation, the shaft resistance was not affected by temperature. This was thought to be due to the pile base load remaining constant, independent of the total load to the pile and temperature variation in and around the pile, however no further explaination was provided. Proper operation of a PFHX is defined by Brandl (2006) as reducing a local ground temperature of $10-15{ }^{\circ} \mathrm{C}$ to approximately $5-10{ }^{\circ} \mathrm{C}$, preventing the formation of ice lenses.

Bourne Webb et al. (2009) and Laloui et al. (2006) also observed pile head displacements of 5mm during their in-situ short term cyclic temperature testing. This provides clear evidence that cyclic temperature variation has the potential 
to affect the settlement and serviceability limit of pile foundations. Particularly concerning from this result is the likelihood of differential settlement across a building's foundation for the case where not all the piles are used as PFHX. The propensity for settlement of the few piles undergoing heating and cooling may unequally share load onto the static piles and risk damaging the building as a result.

\section{Laboratory testing}

Current literature on laboratory testing provides a greater insight to clay response undergoing thermal cycling than that discussed in the case studies. However the major focus until recent times has been the increase in temperature of clays to a greater magnitude than that used in PFHX (as the application under investigation has been the storage of nuclear waste). Recent case studies have provided little insight on the influence of cyclic temperature variation on the ground surrounding a pile foundation, largely focusing on individual clay types and temperature profiles as found in PFHX case studies. Design guides (Ground Source Heat Pump Association 2012) take into consideration only the temperature effect of PFHX rather than the long term effect of heating and cooling of the ground surrounding the pile as the building is heated and cooled. A brief overview of recent laboratory studies is presented below.

\section{Engineering properties}

In early studies, the response of clay to temperature was considered with regard to the shear strength (Mitchell, 1993) volume change and pore pressure variation (Campanella \& Mitchell, 1968). A recent study by Abuel-Naga et al. (2008) has considered the impact of temperature on a range of general engineering properties for geosynthetic bentonite clay layers. These include permeability, compressibility and shear strength through a study on a soft low plasticity clay. Other studies have addressed individual engineering properties including the effect on overconsolidation ratio (Cekerevac \& Laloui, 2004) and plasticity (Towhata et al., 1993). However, these studies have been carried out for a variety of individual clay types and discrete temperature increases. Results from these studies have yet to be unified into a single framework for pile design.

Although not evidenced, Campanella \& Mitchell (1968), Abuel-Naga et al. (2008) and Cekerevac \& Laloui (2004) propose that a change in sample temperature produces a change in the fabric of the clay with interparticle forces and the viscous shear resistance of the absorbed water being affected. The understanding of these changes will significantly aid the future interpretation of thermal cycles.

With regard to the effect of temperature on the stiffness and shear strength of clay, Abuel-Naga et al. (2008) identified that higher temperatures increased the shear strength and stiffness of Bangkok clay, through both drained and undrained testing. However, evidence of this in current literature relating to other clay types has not been identified.

\section{Volume change}

The general effects of temperature, reported by Abuel-Naga et al. (2008) and Cekerevac \& Laloui (2004), on the volume change and compressibility of soil which have been identified are:

- A decrease in soil volume with increase in temperature for normally consolidated and lightly overconsolidated clay, provided temperature is the only variable in testing

- An increase in soil volume with increase in temperature for heavily overconsolidated clay followed by a decrease, provided temperature is the only variable in testing

- Any temperature increase causes an immediate volume change with the managnitude of change dependent on the magnitude of the temperature change

- An increase in compressibility with an increase in temperature

Both authors carried out testing on clay samples of varying overconsolidation ratio and both concluded that the 
stress history of a sample influences the degree of thermal volumetric expansion or contraction produced through heating.

Campanella \& Mitchell (1968) first introduced the idea of volume change, identifing that a reduction in sample height occurred during drained heating of a normally consolidated Boom clay sample. What remains unknown from the investigation is whether this change in sample height was attributed to a change in diameter of the sample (i.e. barreling) or isotropic contraction. Three temperature cycles were carried out on the sample with a temperature change from $4^{\circ} \mathrm{C}$ to $60^{\circ} \mathrm{C}$. Following the heating and cooling cycles, only $47 \%$ of the water was reabsorbed back into the sample following the 3 cycles, indicating an irreversible change occured within the sample. In a second drained test on Boom clay, the sample height was measured through the same 3 temperature cycles. During this test, the original sample height of $89 \mathrm{~mm}$ increased by $3.4 \mathrm{~mm}$ during heating phases. It is possible that radial expansion of the sample may occur due to the isotropic expansion of the sample during heating followed by anisotropic contraction of the sample during cooling, with axial contraction dominating.

Towhata et al. (1993) conducted tests on kaolin and bentonite samples within a temperature controlled oedometer. Samples were incrementally heated whilst their void ratio was monitored. Testing showed that during heating a reduction in void ratio of $3 \%$ for kaolin and $12 \%$ for bentonite was observed. As testing was only for heating, the effect of cyclic void ratio change during the cooling stages could not be determined.It is possible that during the temperature cycles, an increase in pore water pressure within the clay leads to the production of a pseudo consolidation effect. Similarities are thought to exist between temperature induced and pressure induced consolidation effects.

\section{Drainage}

It could be assumed that the clay in which the PFHX is situated will function in an undrained condition during a change in temperature, assuming low permeability clayey ground conditions. This assumption may be too simplistic given the longevity of PFHX. For the case of using a PFHX to heat and cool a building, the temperature cycles being input to the ground have a 12 month period which will allow sufficient time for a proportion of the excess pore water pressure arising from the thermal expansion of water to drain. To achieve this, water must either drain radially from the pile into the surrounding ground or along the pile/soil interface: potentially causing a weakened interface and reducing the shaft resistance of the foundation. Alternatively the drainage may cause clay consolidation, increasing the clay strength immediately surrounding the pile and increasing the foundation strength. This is an area yet to be fully understood.

\section{Overview}

Bringing together the laboratory studies identified, the application of temperature provides a similar response in the clay to a consolidation effect for normally consolidationed samples. In normally consolidated samples, under constant effective pressure, an increase in temperature leads to a reduction in volume as thermal expansion of the water leads to compression the clay and a pressure gradient and flow of water from the sample. Over consolidated samples have been shown to expand initially during heating before following the same trend as normally consolidated samples. The initial expansion may be due to the increase in temperature providing a thermal expansion that is not initially offset by compression of the (stiffer) clay and drainage. However once conditions bring the sample back to normally consolidated behaviour, the sample's volume reduces. The effect of repeated temperatures cycles is yet to be fully understood with regards to how this would influence the structural performance of a PFHX.

\section{UNDERSTANDING CYCLIC EFFECTS}


To further the understanding of the long-term influence of PFHX operation on clays, a series of clay tests has been carried out using a modified triaxial system similar to that developed by Laloui et al. (2006). The system developed at the University of Sheffield incorporates thermocouples alongside a copper heating coil in order to heat and monitor the sample during heating and cooling cycles (Figure 2). This system simulates infield conditions through simultaneous control of the stress and temperature of the sample in the cell.

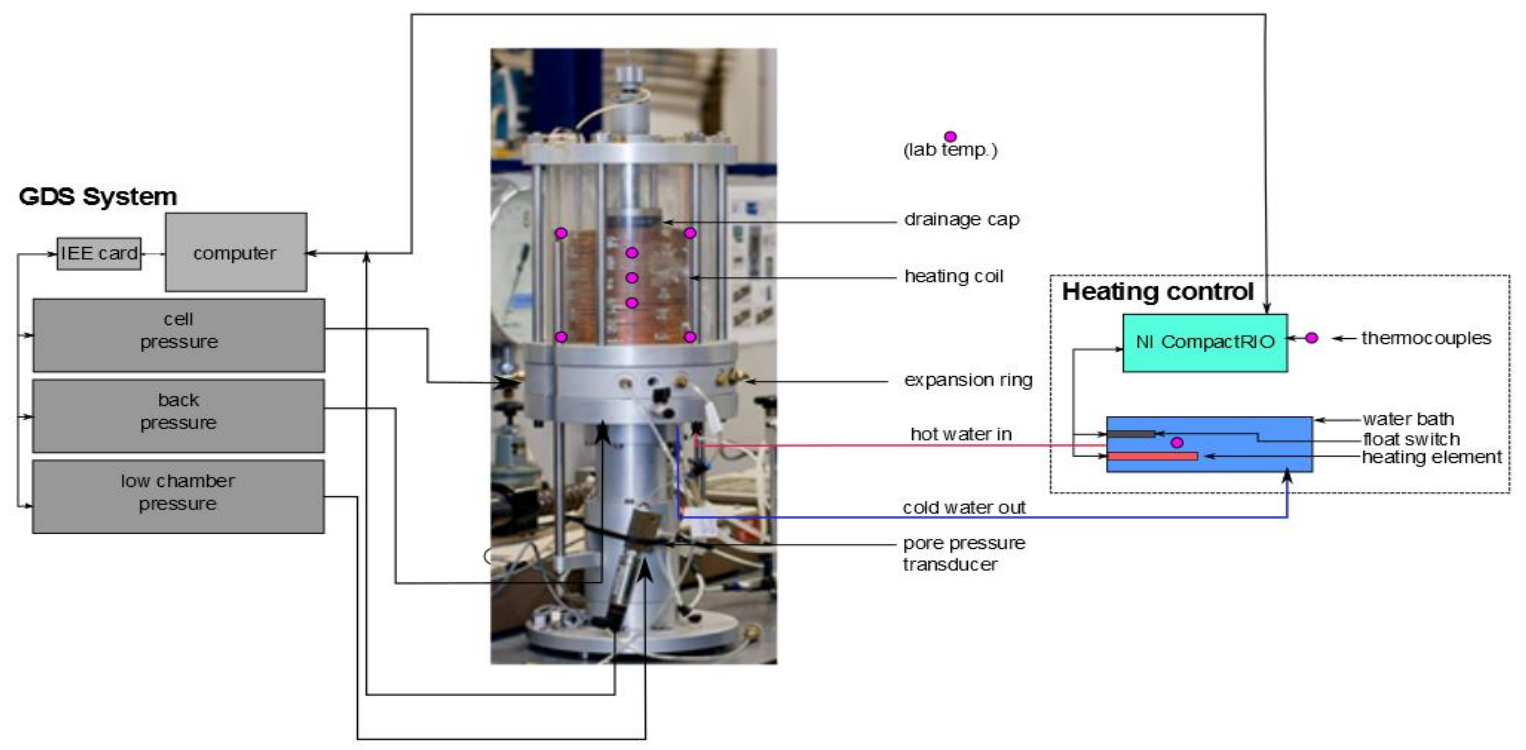

Figure 2 University of Sheffield triaxial system with temperature regulating modifications

An expansion ring at the base of the cell was commissioned for the installation of thermocouples within the cell. These thermocouples are used in the calibration of the test system and monitoring of the temperatures during testing. To regulate the temperature of the cell a bespoke heating system was manufactured. This included a regulated heated water bath and central heating pump with a maximum pressure of 6 bar and a maximum flow rate of $3.5 \mathrm{~m}^{3} / \mathrm{h}$, in order to circulate water at a high enough rate to enable efficient heating within the cell. Staged heating and cooling was carried out using a program developed in National Instruments Labview. This operates as a thermostat, with the desired temperatures being input.

In order to further identify the changes that occur during thermal cycles, local linear variable differential transformers (LVDT) were installed on the outside of the sample. The pressure and volumes within the cell, sample and loading ram were controlled using GDS Instruments pressure transducers. These allowed for an automatic maintenance of pressures independent of volume change.

\section{Test sample}

This study has tested two types of clay of varying plasticity (Table 1), kaolin clay and a glacial till. The samples were produced by consolidating clay slurry (mixed at a ratio by mass of 1:1 with water for kaolin and 1:0.5 for glacial till, approximately twice the liquid limit of the clay) to an effective stress of $500 \mathrm{kPa}$ within a $250 \mathrm{~mm}$ diameter Rowe Cell, maintained at $26^{\circ} \mathrm{C}$. From the large Rowe Cell sample, samples of $50 \mathrm{~mm}$ diameter and $100 \mathrm{~mm}$ in height were cut for testing. By consolidating samples to $500 \mathrm{kPa}$, the samples are significantly stiff, allowing for minimal impact of the local LVDT; on the sample deformation whilst setting up the apparatus. 


\section{Table 1 Atterburg limits and plasticity index for (a) kaolin (as tested by author) (b) glacial till (Glendinning \& Hughes, 2014)}

\begin{tabular}{|c|c|c|c|}
\hline Material & Liquid Limit (\%) & Plastic Limit (\%) & Plasticity Index \\
\hline Kaolin & 63 & 32.3 & 30.7 \\
\hline Glacial till & 45 & 24 & 21 \\
\hline
\end{tabular}

Following saturation samples were isotropically consolidated to an effective stress of $500 \mathrm{kPa}$ within the triaxial system, at $26{ }^{\circ} \mathrm{C}$ (which was the laboratory temperature). The samples should therefore be normally consolidated. During the heating phase the sample was allowed to drain, in order to identify the impact of heating on the volume change of the sample through the amount of water expelled.

The temperature profile is applied to the sample by heating the water bath from $27^{\circ} \mathrm{C}$ to $80{ }^{\circ} \mathrm{C}$ over a period of 6 hours. This resulted in the clay temperature increasing from $\sim 26^{\circ} \mathrm{C}$ to $52{ }^{\circ} \mathrm{C}$ (Figure 3). The sample was then allowed to naturally cool over a period of 6 hours due to the ambient laboratory temperature to $32^{\circ} \mathrm{C}$ before the temperature cycle began again. Subsequent cycles ran from $32{ }^{\circ} \mathrm{C}$ to $52{ }^{\circ} \mathrm{C}$. The sample was allowed to drain freely during these cycles to allow for excess pore water pressure to dissipate. It is recognized that the temperatures profile used within this study is beyond that of normal PFHX operation (typically a maximum temperature of approximately $35{ }^{\circ} \mathrm{C}$ ), however the greater temperature profile allows for a more complete understanding of the impact of temperature on clay.

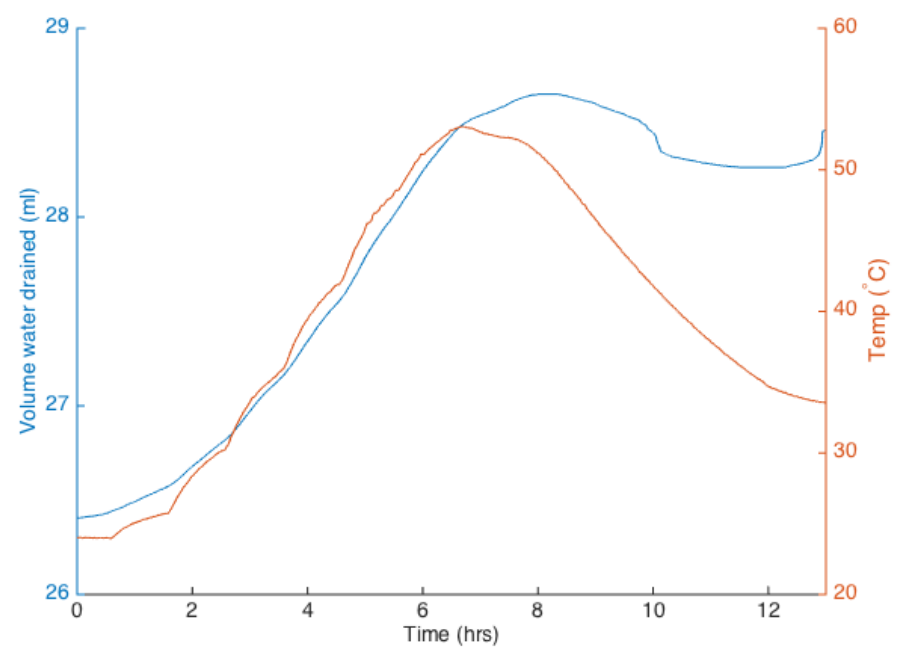

Figure 3 Temperature profile with volume of water drained from the sample

\section{Results}

Figure 4 shows the relative variation in water volume within the samples over the course of the heating and cooling cycles. The initial volume of water within the sample was determined using the samples' moisture content at triaxial set up, with the net volume or 'back volume' measured by the GDS following saturation and consolidation to an 
effective stress of $500 \mathrm{kPa}$. This back-volume figure was measured at a constant temperature at the GDS. The differing y-axis scale between the two graphs highlights the difference in the magnitude of water drained from the sample during the cycles.

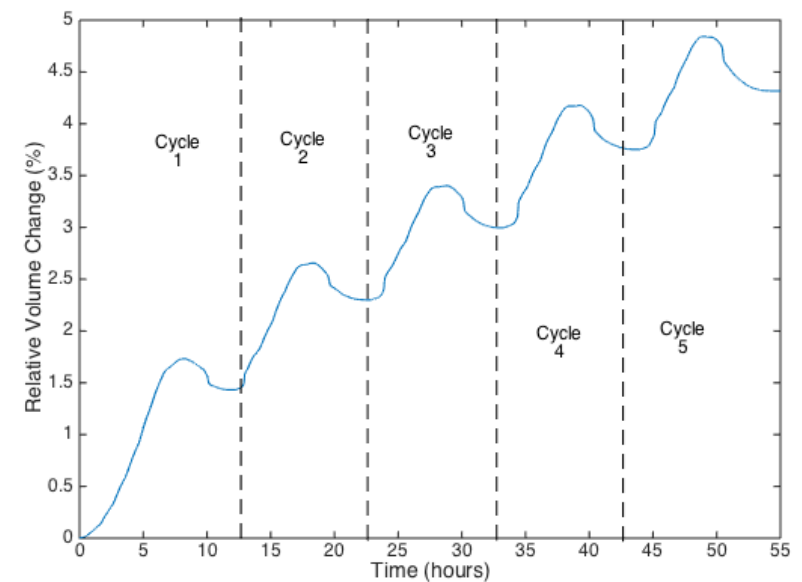

(a)

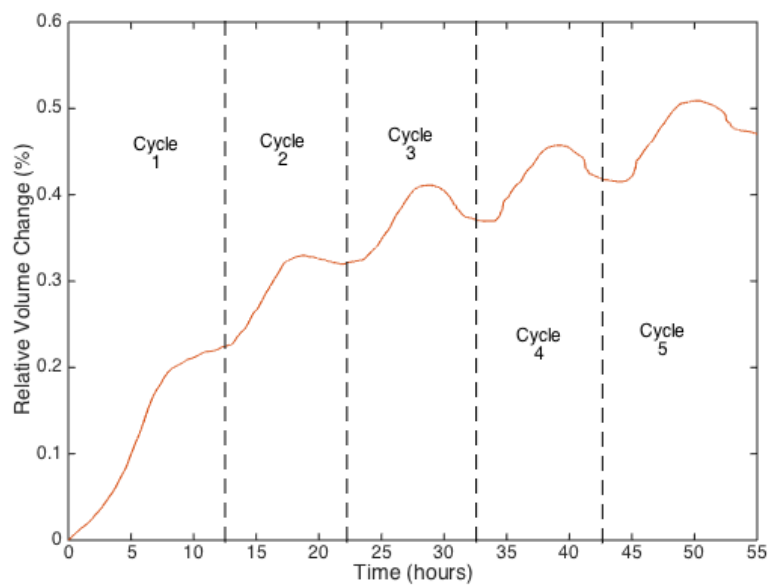

(b)

Figure 4 Back volume measurements during 5 heating and cooling cycles of kaolin using thermal triaxial equipment. (a) 5 cycles kaolin, (b) 5 cycles glacial till.

Both samples showed a permanent loss of water over each thermal cycle, with the initial temperature increase producing the greatest volume change. The drainage and reduction in volume provides further evidence to that discussed previously that temperature induces thermal consolidation effects, mimicking that of stress induced consolidation. The glacial till, with a lower plasticity, appears to be less affected by the temperature variation, displacing only $0.5 \%$ of its initial volume of water over 5 cycles in comparison to kaolin displacing approximately $4.5 \%$ of its initial volume of water.

The kaolin appears to complete its drainage at the end of each cycle indicating that the permeability is high enough to allow this. However for the testing carried out on glacial till, it can be seen that water continues to drain from the sample during the first cycle of cooling. Although not determined for this specific sample, this effect is possibly due to a lower permeability/coefficient of consolidation in the glacial till, leading to the thermal cycling outpacing the drainage.

Over the course of 5 cycles, the net volume of water drained from both samples decreases, with the volume of water drained tending to reduce cycle after cycle. Although not evident from only 5 cycles, it could be thought that over more cycles this difference would continue to reduce, tending to zero additional water being drained during subsequent cycles. Future testing is currently being conducted to identify the change in volume drained over 10 cycles.

\section{DISCUSSION}

This study has found through testing of two different plasticity clays in a modified thermal triaxial cell, that thermal cycles produce a consolidation effect. Such effects need to be extrapolated to the timescales and dimensions of a PFHX system. Considering the core behavior identified with respect to the effect on a PFHX, futher consolidation of the clay surrounding the pile could provide additional strength. However this increase in strength could be compromised by the volume reduction in the clay effectively shrinking away from the foundation, decreasing the shaft resistance whilst increasing the axial load, and also potentially reducing thermal contact between pile and ground, as well as the effect of a preferential drainage path at the pile/soil interface. In addition the volume change has the potential to cause settlement of the ground surrounding the pile and affect the stability of the whole foundation. 
Further testing on a greater number of thermal cycles will provide an insight to these long-term effects.

\section{CONCLUSIONS}

1. The results of cyclic heating/cooling tests on two different plasticity, normally consolidated clays have been reported. 5 cycles of heating/cooling led to a $\sim 5 \%$ volume change in kaolin and a $\sim 0.5 \%$ volume change in a glacial till.

2. The heating cycles generally lead to contraction while the cooling leads to expansion, however the volume is not fully recovered on the cooling phase, leading to an overall 'ratcheting' of volume decrease.

3. It is tentatively postulated that continued cycles will lead to a steady state where expansion/contraction balances. However the overall contraction is likely to lead to settlement around the pile at least during initial operation of the thermal pile.

\section{ACKNOWLEDGMENTS}

This $\mathrm{PhD}$ research has been funded by E-Futures Doctoral Training Centre and the Engineeering and Physical Science Research Council.

\section{REFERENCES}

Bouazza, A., Abuel-Naga, H. M., Gates, W. P., \& Laloui, L. (2008). Temperature Effects on Volume Change and Hydraulic Properties of Geosynthetic Clay Liners. In The First Pan American Geosynthetics Conference \& Exbibition (Vol. C, pp. 102-109). Cancun, Mexico.

Bourne-webb, P. J., Soga, K., \& Amatya, B. (2011). A framework for understanding energy pile behaviour. Proceedings of the ICE Geotechnical Engineering, (2009), 1-8.

Brandl, H. (2006). Energy foundations and other thermo-active ground structures. Géotechnique, 56(2), 81-122. http://doi.org/10.1680/geot.2006.56.2.81

Burghignoli, a, Desideri, A., \& Miliziano, S. (2000). A laboratory study on the thermomechanical behaviour of clayey soils. Canadian Geotechnical Journal, 37(4), 764-780. http://doi.org/10.1139/t00-010

Campanella, R. G., \& Mitchell, J. K. (1968). Influence of temperature variations on soil behaviour. ASCE, 94(3).

Cekerevac, C., \& Laloui, L. (2004). Experimental study of thermal effects on the mechanical behaviour of a clay. International Journal for Numerical and Analytical Methods in Geomechanics, 28(3), 209-228. http://doi.org/10.1002/nag.332

Evidence Directorate. (2009). Ground source heating and cooling pumps - state of play and future trends.

Glendinning, S., \& Hughes, P. (2014). Construction, management and maintenance of embankments used for road and rail infrastructure : implications of weather induced pore water pressures, 799-816. http://doi.org/10.1007/s11440-014-0324-1

Laloui, L., Nuth, M., \& Vulliet, L. (2006). Experimental and numerical investigations of the behaviour of a heat exchanger pile. International Journal for Numerical and Analytical Methods in Geomechanics, 30(8), 763-781. http://doi.org/10.1002/nag.499

Mitchell, J. K. (1993). Fundamentals of soil behaviour. New York, USA: John Wiley \& Sons Inc.

Towhata, I., Kuntiwattanaku, P., Seko, I., \& Ohishi, K. (1993). Volume change of clays indued by heating as observed in consolidation tests. The Japanese Geotechnical Society NII-Electronic Library Service, 33(4), 170-183. 